ISSUES IN PUBLIC HEALTH

\title{
Regulating the South African sport supplement industry: 'Whey' overdue
}

\author{
K Naidoo, ${ }^{1}$ BPharm; R Naidoo, ${ }^{2} \mathrm{PhD} ;$ V Bangalee, ${ }^{1} \mathrm{PhD}$ \\ ${ }^{1}$ Discipline of Pharmaceutical Sciences, School of Health Sciences, Westville Campus, University of KwaZulu-Natal, Durban, South Africa \\ ${ }^{2}$ Discipline of Biokinetics, Exercise and Leisure Sciences, School of Health Sciences, Westville Campus, University of KwaZulu-Natal, Durban South Africa
}

Corresponding author: V Bangalee (bangalee@ukzn.ac.za)

The South African sport supplement industry has experienced rapid growth in recent years. Despite the massive market demand, this industry remains poorly regulated. From raw ingredient contamination to label compliance discrepancies, the sport supplement industry is an area of growing concern and warrants further public debate.

S Afr Med J 2018;108(3):166-167. DOI:10.7196/SAMJ.2018.v108i3.12961

The global sport supplement industry has experienced unprecedented growth in recent years, being equally lucrative in South Africa (SA), where it is growing at an annual rate of $7.7 \%$ (in line with the global compound annual growth rate of $6.8 \%) \cdot{ }^{[1]}$ Despite the massive worldwide and local demand, this industry remains poorly regulated. From raw ingredient contamination to label compliance discrepancies, the sport supplement industry is an area of growing concern.

Supplementation to increase athletic performance has been documented as early as $776 \mathrm{BC}$ by the Greek Olympians, who reportedly used substances such as dried figs, mushrooms and strychnine as ergogenic aids. ${ }^{[2]}$ Since then, the industry has evolved, and when the International Olympic Committee (IOC) banned steroids in the 1960s, the focus shifted to enhancing athletic performance by means of supplementation. The use of supplements among athletes is well documented. The literature estimates that it ranges between $40 \%$ and $88 \%$, depending on several factors, e.g. type of sport, culture, age and gender. ${ }^{[3]}$

Currently, supplementation is no longer limited to athletes or fitness professionals. Its use has extended to those who visit the gym daily and health-conscious individuals. These people represent a major market for the sport supplement industry because of their increasing numbers and the enhanced accessibility to several sport foods and nutritional supplements. ${ }^{[3]}$ Despite the various health, nutritional and immune improvement claims, the exact benefits of sport supplements have not been well established. Many sport supplements currently on the market are likely to be little more than placebos, containing either grossly under-dosed products or ingredients with no proven benefit. ${ }^{[3]}$ In a largely unregulated industry, consumers who complement their diet with supposedly safe and effective supplements, may be doing so to their own detriment, particularly when these are used in high doses or without medical supervision.

A 2001 study illustrated the risk that the lack of governance of the supplement industry can have on the consumer. ${ }^{[4]}$ US researchers conducted a study of over-the-counter pro-hormones (legal at the time), where only 1 of 12 products was found to comply with the regulations of the Dietary Supplement Health and Education Act of 1994. One of the products even contained testosterone, a banned and controlled substance.
In 2004, a study commissioned by the IOC tested 634 non-hormonal sport supplements from 13 different countries. ${ }^{[5]}$ Ninety-four of these products tested positive for anabolic androgenic agents (banned in the World Anti-Doping Agency list and regarded as controlled substances). These agents were not declared on the label and raised the question of how the contamination occurred. Similarly, such agents were also found in seemingly harmless vitamin C and magnesium preparations. ${ }^{[5]}$ Contamination is believed to have been linked to production in a Chinese facility that produced prohormones.

The US Food and Drug Administration (FDA) have thus far identified 767 products marketed as dietary supplements with pharmaceutical ingredients, labelled or unlabelled, included in these products. The FDA further acknowledged that these are possibly only a fraction of the hazardous products currently available. ${ }^{[6]}$ The list includes the banned appetite suppressant sibutramine, erectile dysfunction agents sildenafil and tadalafil, the antidepressant fluoxetine, diuretics such as furosemide, as well as banned stimulants and steroids. The lack of control when a new dietary supplement enters the US market exposes consumers to potentially harmful products that have not been screened. Methylsynephrine (a derivative of ephedrine), methylhexanamine, pure caffeine powder and Acacia rigidula, among many other dietary ingredients, were available on the US market before mounting safety concerns led to their withdrawal. Pure caffeine powder resulted in the death of 2 teenage athletes, ${ }^{[7]}$ while methylhexanamine was linked to the death of 2 US soldiers. ${ }^{[8]}$ The US supplement industry represents a case study, highlighting the need for effective premarket control of dietary supplements to ensure a safer and more reputable industry.

The SA Institute for Drug-Free Sport shares the abovementioned concerns in their position statement for the use of supplements by athletes. Poor consumer awareness and governance regarding the safety of these products have meant that consumer demand for these substances remains high, with little impetus for companies to change the status quo. ${ }^{[9]}$ The lack of consumer awareness with regard to the supplement industry creates a false perception that products are regulated as medicines. ${ }^{[10]}$ This provides supplement users with an unfounded sense of security that label claims and efficacy adherence have met premarketing control. ${ }^{[1]}$ 
SA consumers find themselves at risk owing to the lack of control in the industry. ${ }^{[12]} \mathrm{A}$ study by Opperman and Benade ${ }^{[13]}$ indicated that more than half of the omega-3 fatty acid products available in SA do not adhere to label claims for eicosapentaenoic acid (EPA) and docosahexaenoic acid (DHA) content. Another local study commissioned by Dis-Chem tested 70 different protein products from various SA companies. ${ }^{[14]}$ Local manufacturers Supplements SA and NutriTech were among the lowest rated, with discrepancies in constituent content of up to $80 \%$ less than quoted on the label. Among those that ranked highest were Dis-Chem's house brand, Biogen, and the parent company, USN. A study conducted at an SA National Accreditation System (SANAS)-accredited facility used the Dumas method for the analyses. This method tests the total nitrogen content of a product. A major concern regarding this method is that all amino acids contain nitrogen. Manufacturers may add free-form amino acids (cheaper than protein powder) together with minimal actual protein content and obtain a favourable test result. It would be suitable to follow this up with a test of the amino acid profile of the previously tested products to ensure that the content specified by the manufacturer meets that of the product.

The importance of developing research that centres on verifying label adherence of products and consequently naming the noncompliant companies represents the first step in ensuring a reputable supplement industry in the country. The Dis-Chem study highlighted the need for more stringent regulations in the sport supplement industry. Some manufacturers were able to grossly dilute protein powder, with no concern for label compliance, which is extremely concerning for consumers.

In SA, the sport supplement market is expected to undergo several regulatory changes within the next few years. This is attributed to the establishment of the SA Health Products Regulatory Authority (SAHPRA), which is due to supersede the Medicines Control Council (MCC) within the next year. Among the expected changes are that products making medicinal claims (e.g. testosterone boosters, fatloss agents) will be marketed as medicines and will consequently fall under the Medicines and Related Substances Act 101 of 1965. ${ }^{[14]}$ Furthermore, products falling outside of this bracket and not sold in tablet, capsule or soft-gel dosage forms are to be marketed as foods (as currently) and will be regulated under the Department of Health R429 Draft Regulations Relating to the Labelling and Advertising of Foods. ${ }^{[15]}$ Such products include whey protein and other protein powder blends. The use of whey protein is particularly popular among athletes and fitness enthusiasts, as research indicates that these products may assist in decreasing body fat ${ }^{[16]}$ and increasing lean muscle mass. ${ }^{[17]}$ The development of the Department of Health R429 Draft Regulations Relating to the Labelling and Advertising of Foods and the concern for label compliance within the sport supplement industry therefore warrant an in-depth test to ascertain label compliance to determine, and maintain, the integrity of the supplement industry in SA.

A limited number of studies have analysed the content of products to ascertain ingredient verification and relevant safety data. This can be viewed as a first step towards larger accountability by manufacturers to create a more transparent supplement industry. The advent of the Department of Health R429 Draft Regulations Relating to the
Labelling and Advertising of Foods with regard to product adherence to guideline requirements can be used to determine the readiness of the supplement industry. Furthermore, before more money is spent conducting research on the next potential ergogenic aid, adherence within the local (and international) supplement industry to label claims must be ensured to enable athletes and other individuals to safely and confidently use sport supplements.

\section{Acknowledgements. None.}

Author contributions. All authors contributed to the article.

Funding. Research reported in this publication was supported by the Fogarty International Centre (FIC), National Institutes of Health Common Fund, Office of Strategic Coordination, Office of the Director (NIH/CF/OSC/OD), Office of AIDS Research, Office of the Director, NIH (OAR/OD/NIH), National Institute of Mental Health of the NIH (NIMH/NIH) under Award Number D43TW010131. The content is solely the responsibility of the authors and does not necessarily represent the official views of the NIH.

Conflicts of interest. None.

1. Insight Survey. Have vitamins and supplements become essential in South Africa? 2016. http:// www.insightsurvey co za/blog/a-global-microcosm-the-symmetry-of-sas-vitamin-and-supplementindustry (accessed 20 September 2017).

2. Grivetti LE, Applegate EA. From Olympia to Atlanta: A cultural-historical perspective on diet and athletic training. J Nutr 1997;127(5):860S-868S. https://doi.org/10.1097/00017285-199611000-00004 3. El Khoury D, Antoine--onville S. Intake of nutritional supplements among people exercising in gyms in Beirut city. J Nutr Metab 2012;25:1-12. https://doi.org/10.1155/2012/703490

in Beirut city. J Nutr Metab 2012;25:1-12. https://doi.org/10.1155/2012/703490 4. Green GA, Catlin DH, Starcevic B. Analysis of over-the-counter dietary su
2001;11(4):254-259. https://doi.org/10.1097/00042752-200110000-00008

5. Geyer H, Parr MK, Mareck U, Reinhart U, Schrader Y, Schänzer W. Analysis of non-hormonal nutritional supplements for anabolic-androgenic steroids - results of an international study. Int J Sports Med 2004;25(2):124-129. https://doi.org/10.1055/s-2004-819955

6. US Food and Drug Administartion. Tainted products marketed as dietary supplements. 2016. http://www.accessdata.fda.gov/scripts/sda/sdNavigation.. fm? filter $=\&$ sortColumn $=5$ a\&sd $=$ tainted supplements_cder\&page $=1$ (accessed 11 January 2018).

7. US Food and Drug Administartion. Tragic deaths highlight the dangers of powdered pure caffeine. 2014. https://blogs.fda.gov/fdavoice/index.php/2014/12/tragic-deaths-highlight-the-dangers-of-powderedpure-caffeine/ (accessed 27 September 2017).

8. Eliason MJ, Eichner A, Cancio A, Bestervelt L, Adams BD, Deuster PA. Death of active duty soldiers following ingestion of dietary supplements containing 1,3-dimethylamylamine (DMAA). Mil Med 2012;177(12):1455-1459. https://doi.org/10.7205/milmed-d-12-00265

9. South African Institute for Drug-Free Sport. Position statement of the South African Institute for DrugSouth African Institute for Drug-Free Sport. Position statement of the South African Institute for Drug-
Free Sport. The use of supplements in sport in adults. 2011. http://www.drugfreesport.org.za/wp-content/ Free Sport. The use of supplements in sport in adults. 2011. http://www.drugfreesport.org.za/wp-cont
uploads/2016/03/SAIDS-Position-Statement-ADULTS-version4.pdf (accessed 12 September 2017).

10. Gibson JE, Taylor DA. Can claims, misleading information, and manufacturing issues regarding dietary supplements be improved in the United States? J Pharmacol Experient Ther 2005;314(3):939944. https://doi.org/10.1124/jpet.105.085712

11. Carvey CE, Farina EK, Lieberman HR. Confidence in the efficacy and safety of dietary supplements among United States active duty army personnel. BMC Comp Altern Med 2012;12(1):182. https://doi. org $/ 10.1186 / 1472-6882-12-182$

12. Gabriels G, Lambert M, Smith P, Hiss D. Will the new Consumer Protection Act prevent harm to nutritional supplement users? S Afr Med J 2011;101(8):543-545. https://doi.org/10.1186/s12937-015-0055-7

13. Opperman M, Benade AS. Analysis of omega-3 fatty acid content of South African fish oil supplements. Cardiovasc J Afr 2011;22(6):324-329. https://doi.org/10.5830/cvja-2010-080

14. Schönfeldt HC, Hall N, Pretorius B. Understanding label compliance of high-protein sports supplements to inform regulations. Short report. University of Pretoria. 2015. http://www.up.ac.za/media/shared/238/
to to inform regulations. Short report. University of Pretoria. 2015. http://www.up.ac.za/media/
final-short-report-protein_-supplements-project.zp70711.pdf (accessed 11 January 2018).

final-short-report-protein_-supplements-project.zp70711.pdf (accessed 11 January 2018).
15. Department of Health, South Africa. Foodstuffs, Cosmetics and Disinfectants Act of 1972. Draft . Department of Health, South Africa. Foodstuffs, Cosmetics and Disinfectants Act of 1972. Draft
Regulations: Relating to the Labelling and Advertising of Foods. Government Gazette No. 37695, 2014. Regulations: Relating to the Labelling and Advertising of
(Published under Government Gazette Notice R429.)

16. Baer DJ, Stote KS, Paul DR, Harris GK, Rumpler WV, Clevidence BA. Whey protein but not soy protein supplementation alters body weight and composition in free-living overweight and obese adults. J Nutr 2011;141(8):1489-1494. https://doi.org/10.3945/jn.111.139840

17. Kerksick CM, Rasmussen CJ, Lancaster SL, Magu B. The effects of protein and amino acid supplementation on performance and training adaptations during ten weeks of resistance training. J Strength Condition Res 2006;20(3):643. https://doi.org/10.1519/r-17695.1

Accepted 13 November 2017 